FIU Law Review

Fall 2015

\title{
Perfectionism and Fundamentalism in the Application of the German Abortion Laws
}

Mary Anne Case

University of Chicago Law School

Follow this and additional works at: https://ecollections.law.fiu.edu/lawreview

Part of the Other Law Commons

Online ISSN: 2643-7759

\section{Recommended Citation}

Mary A. Case, Perfectionism and Fundamentalism in the Application of the German Abortion Laws, 11 FIU L. Rev. 149 (2015).

DOI: https://dx.doi.org/10.25148/lawrev.11.1.11

This Article is brought to you for free and open access by eCollections. It has been accepted for inclusion in FIU Law Review by an authorized editor of eCollections. For more information, please contact lisdavis@fiu.edu. 


\title{
Perfectionism and Fundamentalism in the Application of the German Abortion Laws
}

\author{
Mary Anne Case*
}

When I arrived in Germany a decade ago to look more closely at the application of the German abortion laws, I did so with a feminist chip on my shoulder. I was convinced that the application of the laws was disrespectful of women's dignity and autonomy, in ways that should be equally troubling to supporters and opponents of abortion rights. I was also, as a constitutional lawyer, convinced that the compromise the German legislature and Constitutional Court had reached after the re-unification of East and West Germany was hopelessly incoherent and rife with contradictions, such that it made no logical sense from any jurisprudential perspective. What I heard from the Germans I talked to gave me pause, however. No matter what their ideology or level of engagement with abortion questions, all sorts of people, from government officials, scholars, and activists to ordinary citizens, old friends, and relatives, had the same reaction when I told them of my project. "Abortion?" they said. "Why are you looking into abortion? That used to be an interesting question. It's not interesting anymore."

This put my project in a whole new light. When it comes to abortion, the United States throughout my lifetime has been a victim of the proverbial Chinese curse, "May you live in interesting times." If Germans, who

Arnold I. Shure Professor of Law, University of Chicago Law School and Fernand Braudel Fellow, European University Institute. This essay is a lightly revised and updated version of one previously published in CONSTITUTING EQUALITY: GENDER EQUALITY AND COMPARATIVE CONSTituTiONAL LAW (Susan H. Williams ed., 2009). It sets out in abbreviated form portions of my broader work on feminist fundamentalism and on the viability of the German abortion compromise, which I have presented at venues too numerous to list here and on which I have received help from more people than I now have space to thank by name. I am most grateful to the FIU Law Review, Religion and the Law Symposium adviser Eloisa Rodriguez-Dod, Editor-in-Chief Dominique Pando Bucci, and her colleagues for inviting me to participate in their symposium and for facilitating the essay's publication in this issue. I am also grateful to the American Academy in Berlin's Bosch Public Policy Fellowship for funding my research in Germany; to the many participants in the shaping and application of the German abortion laws who took time to speak with me about them, most especially officials of Donum Vitae, including Maria Geiss-Wittmann and Beatrix Frank-Bauer; but also officials in Pro Familia, the Bundesministerium der Justiz, the Bundesministerium für Familie, Senioren, Frauen und Jugend; the Bavarian Staatsministerium für Gesundheit, Ernährung und Verbraucherschutz; the Bavarian Staatsministerium für Arbeit und Sozialordnung, Familie und Frauen; Ernst-Wolfgang Böckenförde, and Rita Süssmuth; to Sabine Berghahn and Kari Robinson for sharing with me their ongoing work on abortion in Germany; to Susan Williams as organizer and to the other participants in the Constituting Equality conference; and to Lyonette Louis-Jacques, Deborah Megdal and Margaret Schilt for research assistance. 
through much of the twentieth century debated abortion questions as fiercely as Americans did, had found a way to lift the curse, perhaps there was something to be said in favor of the German approach.

This essay examines aspects of the German approach at the turn of the millennium and of the politics surrounding first trimester abortions in Germany from the 1990s to the present from the perspective of a distinction between "perfectionist" and "fundamentalist" approaches. ${ }^{1}$ As I define them herein, a fundamentalist approach is one in which no compromise on the commitment to principle is acceptable, but the fundamentalist does not necessarily insist on imposing his or her principles on others. A perfectionist approach has as its goal compliance by all with the perfectionist's principles, but the perfectionist may be willing to engage in some compromise in order to come closer to achieving this goal. The essay suggests that with respect to abortion, the German legal system advances its perfectionist goals by repudiating fundamentalism, because it compromises on the condemnation of abortions in favor of measures to more effectively reduce their number.

I then set forth some of my own concerns about the German approach, from a perspective I call feminist fundamentalism, by which I mean an uncompromising commitment to the equality of the sexes as intense and at least as worthy of respect as, for example, a religiously or culturally based commitment to female subordination or fixed sex roles. ${ }^{2}$ The essay ends with an examination of implications for efforts to move abortion questions past a clash of absolutes ${ }^{3}$ to be found in the Vatican's decade long struggle beginning in the mid-1990s to re-assert Catholic fundamentalist opposition to abortion in the face of efforts by a majority of German Catholic bishops and laity to continue their co-operation in the German compromise.

\section{GERMAN ABORTION LAW FROM THE 1970S UNTIL GERMAN RE-UNIFICATION}

The German and American constitutional laws of abortion have been interesting mirror images of one another for the last several decades. In both the Federal Republic of Germany and the United States in the 1970s, courts

1 I am using the words "fundamentalist" and "perfectionist" here in ways I will try to define precisely, which have a family resemblance, but not perfect identity, with the way the terms are used by others or in other contexts. I realize this may cause some confusion, but I have been unable to find other established or better words for the distinction I am trying to draw, nor have I found a single, consistently used alternate definition of either of the terms I am using.

2 See Mary Anne Case, Feminist Fundamentalism as an Individual and Constitutional Commitment, 19 AM. U.J. GENDER SOC. POL'Y \& L. 549 (2011), www.wcl.american.edu/journal/ genderlaw/documents/5_19.2.Case.pdf.

3 See generally Laurence H. Tribe, Abortion: The Clash of Absolutes (1990). 
overturned on constitutional grounds legislative schemes governing abortion. In the United States, beginning with Roe v. Wade in $1973,{ }^{4}$ the Supreme Court struck down restrictive criminal laws on abortion as incompatible with the pregnant woman's constitutional rights. By contrast, in its Judgment of February 25, 1975, the German Federal Constitutional Court ("Bundesverfassungsgericht") struck down a proposed decriminalization of most abortions performed within the first twelve weeks of pregnancy as incompatible with the fetus's constitutionally guaranteed right to life and human dignity. ${ }^{5}$ According to the Bundesverfassungsgericht, the German state was under an affirmative obligation to protect the fetus "even against the mother." The Bundesverfassungsgericht majority acknowledged that other Western constitutional democracies, such as the U.S., had reached a different result, but insisted that, given the particular history of Germany, the need thoroughly to repudiate the National Socialist policy of "destruction of life unworthy of life" ${ }^{\circ}$ obliged the Federal Republic to be even more protective than other nations of human life and dignity. (According to the dissenting opinion, Germany's need to repudiate its Nazi heritage should instead, when it comes to abortion, lead to "the reverse conclusion, that is, restraint in employing criminal punishment.") ${ }^{7}$

Like the United States Supreme Court with its trimester framework, the Bundesverfassungsgericht did not stop at striking down abortion legislation, but went on to propose a constitutionally acceptable framework for regulating abortion. Under what was known as the Indications Model outlined by the Bundesverfassungsgericht in its 1975 opinion and enacted into federal legislation in 1976, abortion remained a criminal offense except in those enumerated circumstances where expecting the woman to carry the pregnancy to term would be "too much to expect" ("unzumutbar"). These circumstances, or indications, included threats to the life or health of the pregnant woman ("medical indication"), a pregnancy which was the result of a criminal act such as rape or incest ("criminological indication"), a fetus suffering from severe birth defects ("embryopathic indication") and a more general "social indication" or "situation of need" intended to cover circumstances in which continuing the pregnancy would impose on the pregnant woman exceptional hardships comparable in severity to those

4 Roe v. Wade, 410 U.S. 113 (1973).

5 Bundesverfassungsgericht [BVerfG] [Federal Constitutional Court], 39 ENTSCHEIDUNGEN DES BUNDESVERFASSUNGSGERICHTS [BVERFGE] 1, 1975 (Ger.). For an English translation of this decision, see West German Abortion Decision: A Contrast to Roe v. Wade, 9 J. MARshall J. PraC. \& ProC. 605 (Robert E. Jonas \& John D. Gorby trans., 1976).

639 BVERFGE 1, § C (I) (1) (a) (Ger.).

$7 \quad$ Id. at $\S$ A (II) (Rupp-von Brünneck \& Simon, JJ., dissenting). 
encompassed by the other three enumerated indications. It was left to physicians to determine whether any of the indications were present.

Like Roe v. Wade, ${ }^{8}$ the 1975 Bundesverfassungsgericht abortion decision resulted in considerable controversy and political agitation. Statistics indicating that over 80 percent of reported abortions performed under the indications regime fell under the so-called social indication led opponents of abortion to claim that the law was being applied too liberally. As in the United States, abortions were as a practical matter easier to obtain in some regions of the country than in others. Particularly in the more conservative, Catholic regions of Germany, women had more difficulty obtaining abortions and doctors who accommodated them risked prosecution. Abortion rights advocates described as a witch hunt the widely publicized 1988 criminal trial of a doctor from the small Bavarian town of Memmingen charged with more than 150 instances of unwarranted use of the social indication. ${ }^{9}$ Women, too, risked prosecution, among them not only the Memmingen doctor's patients, but West German women who traveled for their abortions to the less-restrictive Netherlands and were met at the border on their return by police searching for evidence they had had an abortion while abroad. ${ }^{10}$

Nevertheless, it took the re-unification of East and West Germany to prompt the German legislature and court systematically to revisit the abortion question. In the period from 1972 until unification, women in the German Democratic Republic had available to them not only what amounted to abortion on request in the first trimester but also free contraception and a much more extensive and readily available system of state-sponsored childcare than was available to women in the Federal Republic of Germany. So attached were the East Germans to this aspect of their laws that, even though at the moment of unification in 1990 virtually all other East German laws vanished in an instant to be replaced by their West German counterparts, the East German abortion laws remained temporarily in place, applicable only to women from the former East Germany for a two year moratorium period during which the united German legislature was to seek a compromise solution. Of course, anyone who took constitutional law seriously had to wonder exactly what sort of compromise could be possible, given that the Bundesverfassungsgericht's 1975 decision rested in part on the Basic Law's Article 1 guarantee of the inviolability of human dignity, which, as a reaction against Nazi violations

8 Roe v. Wade, 410 U.S. 113 (1973).

9 See, e.g., Joel Connelly, German Women's Dilemma; New Nation Confronts Abortion, Other Issues, SEATTLE-Post InTELLIGENCER, Oct. 5, 1990, at A1.

10 See, e.g., Tamara Jones, Social Policy; Wall Still Divides Germany on the Abortion Question, Los ANGELES TIMES, Oct. 19, 1991, at A4. 
of human dignity, had explicitly been declared in Article 79 (3) of the Basic Law to be unamendable. ${ }^{11}$

\section{THE POST-UNIFICATION COMPROMISE}

As it had been in the 1970s, the German federal legislature, now augmented by representatives from the former East Germany, was more willing than the Bundesverfassungsgericht to liberalize access to abortion. It also insisted, however, that its 1992 Act for the Protection of Prenatal/ Developing Life, Promotion of a More Child-Friendly Society, Assistance in Pregnancy Conflicts, and Regulation of Pregnancy Terminations, colloquially known as the Pregnant Women's and Family Assistance Act, ${ }^{12}$ would be more effective at preventing abortion than the prior legislative framework had been. At the center of the new framework was a retooled version of a counseling requirement for pregnant women which had also formed part of the legislation rejected by the Bundesverfassungsgericht in 1975. The Act also included a congeries of provisions designed to reduce the need for abortion, including mandated increases (at least as compared to what was previously available in West Germany, though not East Germany) in the availability of day care and social assistance such as vocational training and greater protection in housing and employment for pregnant women and the mothers of young children.

In its Judgment of May 28, 1993, the Bundesverfassungsgericht upheld central features of the proposed counseling scheme, while insisting on the revision of other features to make them more unambiguously pro-life. ${ }^{13}$ By the terms of the Pregnant Women's and Family Assistance Act, a woman who wished to obtain an abortion within the first twelve weeks of pregnancy was required to present herself at a government approved and government funded counseling center for counseling to resolve what was described as her "situation of conflict." At the Bundesverfassungsgericht's insistence, the counseling could not be merely informational; rather "the counselors must try to encourage the woman to continue her pregnancy and show her opportunities for a life with the child."14 The court contemplated that the counseling, and that legislation more broadly, should take into

11 Grundgesetz Für die Bundesrepublik Deutschland [Grundgesetz] [GG] [BASIC LAw], May 23, 1949, BundesGesetzBlatt, Teil I [BGBL. I] at arts. 1 (1), 79 (3) (Ger.).

12 Gesetz zum Schutz des vorgeburtlichen/werdenden Lebens, zur Förderung einer kinderfreundlicheren Gesellschaft, für Hilfen im Schwangerschaftskonflikt und zur Regelung des Schwangerschaftsabbruchs [Schwangeren- und Familienhilfegesetz] [Pregnant Women's and Family Assistance Act], 1992, BGBL. I at 1398.

1388 BVERFGE 203 (Ger.). An official English translation is available at www.bundesverfassun gsgericht.de/en/decisions/fs19930528_2bvf000290en.html. Further citations from this opinion in this essay will be to this official translation.

$14 \quad$ Id. at 217. 
account all of the pressures that might bear on a woman, including external pressures from family members, sexual partners, landlords, employers, and creditors. Upon completion of the counseling, the woman would receive a certificate in effect permitting her to obtain a first trimester abortion without risk of criminal sanctions. She no longer had to obtain third-party certification of the existence of one of the four approved indications; the ultimate decision was in her hands. However, because she could not be judge in her own case, in the absence of third-party certification, her abortion, while not punishable, could also not be justified; the Bundesverfassungsgericht insisted it would remain a wrongful act. Consequentially, the court majority determined that the comprehensive public medical insurance scheme could no longer pay for abortions that were not medically necessary. If, however, the woman herself were too poor to pay for the abortion, the court majority held that the state itself was authorized to pay the cost. The Bundesverfassungsgericht also insisted that comprehensive abortion statistics be maintained, because its approval of the substitution of counseling for criminal sanctions was conditioned on counseling being indeed more effective than the threat of punishment in inducing women to carry their fetuses to term. The compromise as amended by the court and eventually embodied in federal legislation in $1995^{15}$ had many other features as well, a full explication of which would exceed the scope of this paper. ${ }^{16}$

Like the U.S. Supreme Court's Casey decision, ${ }^{17}$ the Bundesverfassungsgericht's decision of 28 May 1993 was intended to offer the possibility of a stable compromise. Although starting from opposite positions concerning the constitutionality, in principle, of first trimester abortions, the results reached by the two courts are not as different as their starting points might suggest - the result in both cases is in effect to preclude the state from imposing an undue burden on a pregnant woman through the restrictions it imposes on her termination of her pregnancy, ${ }^{18}$ although in the U.S. the principal reason for doing so is to protect the woman's rights, while in Germany the emphasis is on more effective

15 Schwangeren- und Familienhilfeänderungsgesetz (SFHÄndG) of 21 August 1995.

16 It is particularly important to note that this essay's focus is the legal treatment of first trimester abortions only, not late term abortions. For a more detailed examination of the 1993 decision in comparative perspective, see, e.g., Gerald L. Neuman, Casey in the Mirror: Abortion, Abuse, and the Right to Protection in the United States and Germany, 43 AM. J. CoMP. L. 273 (1995).

17 Planned Parenthood of Southeastern Pa. v. Casey, 505 U.S. 833 (1992).

18 Although the German court's goal is unequivocally to discourage abortions, it nevertheless manifests a concern about undue burden on women contemplating abortion in setting forth detailed mandates about, for example, the provision of a sufficient number of counseling centers within easy reach of all women in Germany, requirements that counseling not be dragged out until it is too late for a woman to abort, and the availability of state funds for the abortions of poor women. 
protection for the fetus. The legal details of both decisions, like those of their predecessor decisions from the 1970s, were readily susceptible to criticism. The German decision in particular was extremely lengthy, complex and full of apparent tensions and contradictions. Not all of the forms of assistance for pregnant women have been implemented as contemplated in Germany. But the German decision seems to have accomplished what the American Casey decision did not-a compromise many of the leading participants in the abortion debates found attractive enough to be worth trying to preserve, even at the expense of ignoring or underplaying any tensions or contradictions. ${ }^{19}$

\section{Perfectionist And Fundamentalist Characteristics Defined}

The remainder of this essay will use an analysis of the salient features of the German abortion compromise to highlight distinctions between what I am calling "perfectionist" and "fundamentalist" approaches to a problem such as the legal regulation of abortion. As I am defining these terms, which I acknowledge others define in somewhat different ways, the hallmark of fundamentalism is an unwillingness to compromise and that of perfectionism is a willingness to impose. Another way of formulating the distinction is that perfectionism speaks in the second or third person-it is about what "you" or "they" should or must do, not just about what "I" or "We" (as in "We the people of the United States ..." respect to any deeply held commitment, it is possible to be both fundamentalist and perfectionist, neither perfectionist nor fundamentalist, fundamentalist without being perfectionist, or perfectionist but not fundamentalist. With respect to any commitment or set of commitments, individual actors within a legal system, as well as the legal system itself, can decide not to compromise without wishing to impose or can decide to impose and perhaps in the interests of that imposition, compromise. In other work, I have explored the distinctions between fundamentalism and perfectionism in ongoing debates on issues including the legal regulation of marriage, veiling and sex segregation, and the teaching of values in public schools. $^{21}$

Before applying these distinctions to the German abortion context, let me offer an illustration from yet another context to help make my rubric clear. Consider a vegan invited to a meal at which the host serves paella, a rice dish made with meat and shellfish. The host's proposed solution is that

19 As will become clear below, I do not mean to suggest that the current state of the law in Germany raises no objections or that all abortion questions are deemed settled.

20 U.S. CONST. pmbl.

21 Case, supra note 2; see also Mary Anne Case, Feminist Fundamentalism on the Frontier Between Government and Family Responsibility for Children, 2009 UTAH L. REV. 381 (2009). 
the vegan guest can just scoop out the pieces of meat and shellfish from the dish. A fundamentalist vegan is someone for whom just scooping them out is not an acceptable option. Some fundamentalist vegans are perfectly comfortable sitting down to a meal at which others are eating meat, so long as their own portion is completely untainted. But one who is also a perfectionist might insist that only vegan food be served to everyone at the table. And one with perfectionist, but not fundamentalist, tendencies might consider it an acceptable compromise if everyone's portion of rice were flavored with shellfish stock, but no other meat or fish were included in the meal.

As I see it, the German abortion compromise as crafted by the legislature and amended by the court is in important ways perfectionist without being fundamentalist. It began from the premise that the most important thing about abortions is not that they be condemned but that they be prevented. Given that the threat of criminal punishment had not worked to prevent abortions, it was possible that counseling, whose purpose was to protect the fetus, not "against the mother" but with her cooperation, could be more effective. Substituting counseling for the threat of punishment was thus worth trying, even though the somewhat paradoxical result was to allow a woman to engage with impunity in a wrongful act contravening constitutional norms provided that she allow government authorized counselors to try to talk her out of it first.

The simultaneous denial of insurance coverage for most abortions and insistence on authorization of government payments for the abortions of poor women is similarly paradoxical from a fundamentalist perspective. Under this scheme, the government will not only be permitting, but paying for, wrongful acts contravening constitutional norms. This introduces a new element into the division of acts along one axis into protected, permitted, condemned and along another into subsidized, unsubsidized, and taxed. While abortion in the United States is famously protected but unsubsidized, ${ }^{22}$ abortion in Germany can be paradoxically at once condemned and subsidized. One way to account for this difference is as an instantiation of the broader contrast between an American commitment to individual rights and responsibilities and a German constitutional commitment that the state be a social state.

Some might be tempted to see a heritage of eugenics in the German government's willingness to pay for the abortions of poor women, a disproportionate number of whom can be predicted to be of other than ethnic German origin. But a closer look at the regulations on abortion

22 See, e.g., Harris v. McRae, 448 U.S. 297 (1980) (upholding prohibition on the use of Medicaid funds to perform abortions except in cases of rape, incest, or danger to the life of the pregnant woman). 
payments and their application reveals the following: it was left to the legislatures, still in general more liberal than the court on abortion issues, to determine what qualified a woman as needy enough to have her abortion paid for by the state. The adopted income thresholds were not only quite generous, but also count only a woman's own income, not that of her spouse or other family members, or her illiquid assets. The result, not until recently widely publicized, is that the state, under a constitutional obligation to prevent abortions, nevertheless pays for more than 80 percent of them. ${ }^{23}$ Again, the court's explanation is one that privileges a perfectionist attempt to prevent abortions over a fundamentalist insistence that the state keep its hands clean: payments for poor women's abortions were necessary to the success of the counseling scheme because without them women might bypass counseling and the services of a licensed physician entirely, risking their health and foreclosing the possibility of effective influence being brought to bear on them.

The Bundesverfassungsgericht's Judgment of May 28, 1993 was not greeted with universal acclaim, with some feminists calling it a "return to the Middle Ages" 24 and some abortion opponents calling it an unprincipled abdication of the state's duty to protect fetal life.

\section{MY FEMINIST FUNDAMENTALIST CONCERNS ABOUT THE GERMAN COMPROMISE}

My own initial reaction to the 1992 decision, from my feminist fundamentalist perspective, ${ }^{25}$ was not enthusiastic. I was particularly troubled that the counseling scheme encourages a view of women as uniquely unable to make responsible decisions without aid. My concerns intensified when I looked at abortion counseling in light of the history of the regulation of women as mothers under German law: until the 1970s, for example, a guardian, with decision-making authority from the state, was required to be appointed for every child of any unmarried mother,

23 The percentage of state financed abortions varies by region, from approximately 65 percent in conservative Catholic Bavaria to approximately 95 percent in more liberal North Rhine-Westphalia. MANFREd SPIEKER, KIRCHE UND ABTREIBUNG IN DEUTSCHLAND: URSACHEN UND VERLAUF EINES KONFLIKTES 105 (2d ed. 2008).

24 Regine Hildebrandt, minister for social affairs in the state of Brandenburg, as quoted in Stephen Kinzer, German Court Restricts Abortion, Angering Feminists and the East, N.Y. TIMES, May 29, 1993, at 1 .

25 Not all feminists, even those who by my terms would be feminist fundamentalists, would agree with me. Like the religious commitments to which I am pressing an analogy in my use of the term "fundamentalist," feminist commitments can vary in content as well as in character. Feminists, like those within a faith tradition, diverge somewhat in their beliefs and in their views of what their beliefs require of them. Moreover, many committed feminists, like many devout religious believers, would not embrace nor be accurately described by the term fundamentalist as I define it. 
regardless of the mother's age, fitness as a parent, economic or educational level. ${ }^{26}$ My concerns would be abated if the counseling scheme were not so anomalous in present-day German law. If, for example, counseling were a well-established, frequently encountered practice under present-day German law, if persons seeking to engage in a wide variety of acts were required to undergo counseling beforehand, my concerns would not be as strong. As things stand, however, pregnant women are uniquely seen as in need of counseling, uniquely requiring guidance in making decisions.

Let me stress three things: First, the response of feminist supporters of the German abortion compromise would be that, in the end, the compromise puts the ultimate decision whether or not to abort in the hands of the pregnant woman; it can thus be seen as more respectful of a woman's decision-making ability than prior schemes, in both Germany and the preRoe v. Wade United States, that put the ultimate decision whether a woman was in a condition of sufficient distress that she should be allowed to proceed with an abortion in the hands of third parties such as doctors. Second, my concerns apply only to mandatory, not to voluntary counseling. Third, these concerns about mandatory counseling, are, in my view, independent of any underlying commitment on abortion. Thus, those who favor abortion rights may see counseling as an acceptable price to pay for the ultimate opportunity to abort, while those who oppose abortion may see counseling as a useful tool for discouraging abortion. On the other hand, an uncompromising focus on sex equality under law might perhaps lead some to the conclusion that it better befits women's dignity as independent responsible legal actors to send them to jail for aborting, rather than to mandatory counseling before they do so.

My own inclination was to compare mandatory abortion counseling to the West German procedure for conscientious objection by young men to mandatory military service ("Kriegsdienstverweigerung"), which traditionally had been more of an adversarial examination than a counseling session. ${ }^{27}$ Unlike pregnant women, young men who sought to qualify for alternative service were not treated as necessarily in need of advice or guidance, but were instead presumed to know their own mind. One could, however, readily imagine how a counseling approach might work. ("Listen, son, it's not really so bad in the army, and the country needs defending, doesn't it? You want to do your part, don't you? Think it over. . ..") To what extent do intractable differences between the two situations and to

26 See, e.g., Elizabeth D. Heineman, What Difference Does a Husband MaKe? Women AND MARITAL STATUS IN NAZI AND POSTWAR GERMANY 151-55 (1989).

27 This procedure is no longer in effect, given that in the united German population at present there are far more young men eligible for potential military service than the German military currently has need to draft. 
what extent do norms of masculinity and femininity help account for the differences in approach? One question worth posing is whether increased and broader applicability of a counseling approach might be beneficial.

A second set of feminist concerns arises for me from the abortion financing regulations put in place after the May 1993 decision. As noted above, regulations implementing the decision interpreted the mother's straitened financial circumstances very broadly, such that, in theory, even the non-wage earning wife of a rich man, because she earns no income and may have no liquid assets in her own name, can qualify for state aid. One under-publicized consequence of these generous regulations is that, in the aftermath of a decision reaffirming abortion's wrongfulness and loudly trumpeting constitutional restrictions on payments for abortions, the overwhelming majority of abortions are paid for by the state. This fact alone is worthy of attention. In addition, however, it is worth noting that the group of women most directly disadvantaged by the 1993 decision are those who could have justified their abortions and had them paid for by insurance under the old scheme but, because they are wage-earners in their own right, must now pay for abortions without being given the same opportunities previously available to justify themselves.

Once again, it seems to me that having concerns from a feminist fundamentalist perspective about this aspect of the abortion decision can be independent of one's underlying views on the abortion question. Supporting evidence for my supposition can be found in the partial dissent of constitutional court judge Ernst-Wolfgang Böckenförde. Abortion rights supporters had urged unsuccessfully that Böckenförde be recused from participating in the Bundesverfassungsgericht's 1993 abortion case because of his prominent support for Catholic anti-abortion organizations. Nevertheless, in his opinion dissenting in part, Böckenförde objected that the majority had unnecessarily denied to women the opportunity previously available to them to justify their abortions:

If women who are considering pregnancy termination are called upon to show responsibility in this way and if they are expected to act according to the requirements of the law, it is then contradictory to demand at the same time a constitutional prohibition whereby in all legal areas, other than penal law, women who have had a termination are to be treated without distinction as having acting wrongly and are to have no chance to defend themselves. Women are supposed to use the legal system's requirements for the protection of unborn life as orientation, nonetheless even when they do their actions are and remain - by virtue of the constitutional order-wrong. That is not only contradictory-it also affects the woman's person, her honor and legal 
status. $^{28}$

In addition to sharing Böckenförde's concerns, I fear that the way this aspect of the decision was ultimately worked out in the abortion funding regime may fit with a broader tendency in German law and society to privilege the interests of housewives more generally over those of independent professional women.

\section{PERFECTIONiSM AND Fundamentalism In The RESPONSE OF THE CATHOLIC CHURCH ${ }^{29}$}

That legislators and judges on various sides of the abortion question in Germany were prepared to compromise in hopes of achieving a stable equilibrium may not seem remarkable. More surprising, perhaps, was the response of a significant majority of the bishops and laity of the German Catholic Church to the substitution of a counseling regime for a regime focusing on criminal punishment as a means of discouraging abortions in the first trimester, as authorized by the Bundesverfassungsgericht. Like the Vatican and the American Catholic Church, the Catholic Church in Germany was strongly opposed to abortion. Nevertheless, the then head of the German Catholic Bishops' Conference, Bishop Karl Lehmann, reacted enthusiastically to the counseling scheme outlined in the Bundesverfassungsgericht's 1993 decision, saying, "the real winner [in this case] is the human being." ${ }^{, 30}$ Bishop Lehmann said he was particularly pleased to see that the new scheme contemplated that the responsibility to protect life would extend beyond the pregnant woman herself into her family and social circle and the society at large.

The court's majority opinion and subsequent legislation set forth in detail the requirement for government funded counseling centers to be set up in all parts of Germany. Initially, some were authorized to be run by the regional governments themselves, others by physicians, and many by Pro Familia (the German equivalent of Planned Parenthood). Remarkably, however, many were also authorized to be run by the Catholic Church (typically through Caritas, the German equivalent of Catholic Charities).

From the beginning, a small minority of German Catholic clergy and laity resisted the involvement of their Church in the new abortion counseling regime, taking a position that was uncompromising, or, in my

28 88 BVERFGE 203, at 427 (Ger.) (Böckenförde, J., concurring in part and dissenting in part).

29 Among the most detailed historical and analytical accounts of the interactions of the German Catholic hierarchy and laity and the Vatican concerning the application of the German abortion laws are two books written from perspectives generally supportive of the Vatican position, Spieker, supra note 23, and Rainer Beckmann, Der Streit um den Beratungsschein (2000) (including full text of relevant documents from 1995-99).

30 BECKMANN, supra note 29 , at 81. 
terminology, fundamentalist, to wit that given that at the end of statesponsored counseling pregnant women were issued a certificate which they could use to obtain an abortion without risk of criminal punishment, the counseling centers were essentially providing these women a license to kill, something the Church and its members ought not to facilitate in any way. ${ }^{31}$

The overwhelming majority of the German Catholic bishops, however, supported the full participation of the Catholic Church in the statesponsored counseling scheme. Even more remarkably, they continued to do so over a period of many years in the face of repeated, increasingly unambiguous and insistent directives from the Vatican and from the Pope himself to stop. The bishops' tenacious but ultimately unsuccessful efforts to dissuade the Vatican from its fundamentalist insistence on keeping the Church from any involvement whatsoever with the German abortion compromise centered on an argument that Catholic counseling centers had an opportunity to dissuade women from aborting and thereby could save the lives of their unborn children. Thousands of children, said the bishops, owed their lives to the Church's counseling centers, and it would be its withdrawal from counseling, rather than its continued participation, that would implicate the Church in the deaths of the innocent.

After evading for five years Vatican-imposed deadlines for ceasing to issue certificates of abortion counseling that could be used to obtain abortions, in the end, the German Catholic bishops were indeed forced to withdraw from participation in state-sponsored counseling, but the place of the Church itself was taken by organizations of committed pro-life Catholic laity, notably Donum Vitae (Latin for "gift of life"), founded for this purpose in September 1999. The Pope and the Vatican then turned their attention to condemning and trying to stop the participation of these organizations of Catholics in abortion counseling. After the elevation to the papacy of German-born Joseph Cardinal Ratzinger, who, while head of the Congregation for the Doctrine of the Faith had himself communicated with the German Bishops directing them to cease and desist offering counseling certificates, his successor as head of what used to be known as the Congregation of the Roman and Universal Inquisition, American Cardinal William Levada, directed the German Bishops to stop Catholics from supporting Donum Vitae. Like the bishops before them, however, the women and men of Donum Vitae resisted the Vatican directives and continued, not only in their counseling, but in their conviction that it was

31 Compare the objections of the Catholic petitioners in Little Sisters of the Poor Home For the Aged v. Sebelius, 134 S. Ct. 1022 (2014), and Zubik v. Burwell, 983 F. Supp. 2d 576 (W.D. Pa. 2015), who similarly object to signing forms or otherwise participating in a process they believe would make them complicit in the provision of contraceptives and abortifacients to their employees under the provisions of the Affordable Care Act. 
consistent with if not required by their Catholic faith.

What lessons can be drawn from the ongoing battle between Donum Vitae and the Vatican over participation in the abortion counseling regime? Well, a pessimist might see evidence that the issue of abortion can never get beyond a clash of absolutes, with fundamentalists ever ready to upset any hope of stable compromise. But, having spent some time with the women of Donum Vitae in Bavaria, I think there might be more optimistic lessons as well, especially when I contrast their approach with that more prevalent among abortion rights opponents in the United States. Unlike so many of the counselors who lie in wait for women at the entrances of abortion clinics in the U.S. or the legislators who seek to mandate counseling for American women seeking abortions, ${ }^{32}$ the women of Donum Vitae, in the spirit of the German constitutional compromise itself, appear to have an approach that is at its root not finger-wagging, but supportive, whose aim is, as the Bundesverfassungsgericht required, to "show [the pregnant woman] opportunities for a life with the child," not to threaten her with regret or cancer should she abort.

Also in the spirit of the German compromise, the Donum Vitae counselors repudiate fundamentalism in the interests of perfectionism. The rules governing abortion counseling require state-sponsored counseling centers also to provide sex education, including the use of contraceptives. Wasn't this difficult for them as Catholics, I asked some of the women of Donum Vitae, given that their Church forbad artificial means of contraception as well as abortion? Of course not, they responded with some puzzlement: every successful contraception is an abortion that does not need to happen; contraception may be bad, but abortion is much, much worse. ${ }^{33}$ Like much about the German compromise, this attitude on the part of Catholic activists is worthy of further study at a time when religious opponents of abortion in the United States are likely to let fundamentalism dictate their agenda, and, in recent years, the agenda of the government actors they can control, opposing not only abortion funding, but also access to and information about contraception.

32 For an overview of U.S. state laws mandating counseling, see Guttmacher Institute, State Policies in Brief as of March 1, 2016: Counseling and Waiting Periods for Abortion available at www.guttmacher.org/sites/default/files/pdfs/spibs/spib_MWPA.pdf.

33 Personal communications with members of Donum Vitae, Munich, Germany, June 2002. 